\title{
Put to Sleep
}

Michael K. Magill, MD

Alan called early in the afternoon. "Please come look at Bob. I don't think I can."

So I canceled the rest of my appointments and drove to Bob and Carl's two-bedroom townhouse. I had been there several times before to see Carl when he was sick. The oleander bushes outside his window still bloomed pink as I pulled in the gravel driveway. Alan and Mary waited outside in the bright sun, sweating. I opened the door to the house, stepped into the dark, and turned left into the cozy kitchen. Bob sat on the aluminum and vinyl kitchen chair, head turned to the side at rest on his folded arms as though he might awake suddenly, startled to have been asleep. Around him was the noisy jumble of life: blender recently grinding, cabinets spilling spice, boxes whispering white dressings, pill bottles cluttering. The home was silent.

Bob had the air of one of those detailed and realistic modern sculptures with the look of live people doing everyday things: vacuuming, playing cards, sleeping. The statues look so ordinary you think they move. You keep looking back to see whether they have.

As I looked at Bob, my mind flooded with recollected, storied images: Bob and Carl working and living overseas, happy in southern Europe; the first purple spot on Carl's skin; the damp hospital cloth in Bob's hand, sponging sweat from Carl's gasping face; the bulge of Bob's biceps, a cradle for Carl in our clinic door before they started staying home; the brightened faces of our nurses, receptionist, and surely myself, as the couple warmed our workplace by their visits; the stump of Carl's leg after the pain became so great he begged and begged me to have it cut short.

Carl had finally died at home 2 months before.

Submitted 10 September 1997.

From the Department of Family and Preventive Medicine, University of Utah School of Medicine, Salt Lake City. Address reprint requests to Michael K. Magill, MD, Department of Family and Preventive Medicine, University of Utah School of Medicine, 50 North Medical Dr, Salt Lake City, UT 84132.
Bob carried his own human immunodeficiency virus infection, we thought, as lightly as he lifted Carl. He had seen me once for his own care, way back, but not again, and I had not heard from him since Carl died. I had not called him, either, to learn of his drinking and hopelessness. Or of the pills he collected as I searched for the strength to ease Carl's pain. Or of the blender. Or of the plans.

In the bright sun again, I faced Alan. His younger brother had died of acquired immunodeficiency syndrome (AIDS), so he joined the AIDS support service when few did. Mary stood close to Alan. Angry tears sparkled cheeks. "How could he do that?" I had added my guilt, secretly like poison, to the fatal cocktail, "Why hadn't I called?"

Now, years later, I still feel the anger, guilt, and sadness, but they have gentled. Wallace Stegner spoke of the "angle of repose," at which piled stones and dirt stop tumbling. He also said it is "the angle at which a man or woman finally lies down."1 My emotions are now like stones on the hillside-lying down, rough, but still. Since their tumbling stopped, I can see the enduring shape of what Bob and Carl gave us while both were alive: a demonstration of how to love without reserve. I think that is why we all smiled, despite the pain of their illnesses, when they were with us. Seeing their love gifted hope to each of us who knew them.

I no more cast reproach toward the still-life memory of Bob, seated dead in their kitchen. I wish he had lived, had had a way to find hope, to let someone carry him as he had carried Carl. I still feel guilt that I was not a better doctor for him. I ache for his loneliness, but I now understand his suffering and fear were too great for what he could bear. I think of the mercy he sought in death, a treasured life put to sleep, to rest from too much pain. And I am startled to realize their love would not be so vivid a memory had Carl not died in agony from AIDS and Bob from suicide.

\section{Reference}

1. Stegner W. Angle of repose. New York: Penguin Books, 1971:568. 